\title{
Real-time measurement of machine tool temperature fields and their effect on machining errors
}

\author{
C. Chen*, J. F. Zhang**, Z. J. Wu***, P. F. Feng**** \\ *Tsinghua University, DPIM, Beijing 100084, P.R. China, E-mail: ccyxql@gmail.com \\ **Tsinghua University, DPIM, Beijing 100084, P.R. China, E-mail: zhjf@tsinghua.edu.cn \\ ***Tsinghua University, DPIM, Beijing 100084, P.R. China, E-mail: wuzhijun@tsinghua.edu.cn \\ ****Tsinghua University, DPIM, Beijing 100084, P.R. China, E-mail: fengpf@tsinghua.edu.cn \\ crossref http://dx.doi.org/10.5755/j01.mech.17.4.572
}

\section{Introduction}

Thermal origin errors play a critical role in the machining accuracy achieved when using machine tools and significantly influence the surface quality of the finished workpiece. The origin and formative cause of certain machining errors has been observed to be closely linked to the temperature of critical elements of the machine tool [1, 2]. When a machine tool is working, the temperatures of various components vary with position and the influence of various heat sources. Owing to the complexity of the nature and distributions of the heat sources, non-uniform temperature fields are formed in the mechanical components of the machine tool. So different degrees of thermal expansivity are generated in different components of the machine tool, and the original relative positions between the components are altered. Accordingly, the machining accuracy of the machine tool will decrease. For instance, in high speed precision machining, friction heats the spindle bearing, leading to a rapid increase in temperature. Thermal origin errors can account for as much as $50-70 \%$ of the dimensional errors on a machined workpiece [3-5]. Therefore, it is important to understand the thermal performance of machine tools.

It is intuitive and effective to study the thermal performance of machine tools by experiment, in this case by measuring temperature fields and thermal origin errors. The experimental method for the thermal performance of machine tools requires the following: temperature measurement, machining error measurement, and data analysis and processing. For temperature measurement, infrared thermal imaging, fast photoelectric sensor temperature measurement and thermocouples are used to capture the temperature distribution in machine tools $[6,7]$. For machining error measurement, the 1-D ball array, the doubleball-bar, machine checking gauges, dual-frequency laser interferometry, laser displacement sensors and eddy current displacement sensors are used to detect the results of machine tool thermal variation [8-13]. To process and analyze the data from these measurements, and to determine the relationship between thermal origin errors and time and the relationship between temperature fields and time, the commonly used data processing methods are list, graphical and calculation methods. This paper describes a temperature measurement system using platinum resistance temperature sensors to detect changes in temperature fields, and a displacement measurement system with two laser displacement sensors and an eddy current displacement sensor to measure thermal origin machining errors. The graphical method is used to analyze the data.

\section{Construction of a real-time measurement system}

Thermal origin of machining errors. In general, possible heat sources that might lead to thermal origin errors in machine tools are bearings, motors, gears, drives, pumps, motors, the action of cutting, and external heat sources. To measure all the possible heat elements and consider the temperature fields over the whole machine, a large number of temperature sensors are needed. However, even given a large number of sensors, it is impossible to directly measure all these heat elements under a particular and repeatable set of work conditions. Therefore, it is necessary to consider a simplified set of main factors as measurable heat elements, namely the machine tool spindle bearings and the spindle drive motor [14].

Real-time measurement system. Based on the above analysis, a real-time measurement system for thermal and mechanical performance was constructed. As is shown in Fig. 1, the system is composed of four parts: measurement sites on the machine tool, the displacement measurement system, the temperature measurement system and a PC based data processing system.

To get a precise temperature distribution in the test machine tool, 32 platinum resistance temperature sensors were fixed onto the surface of the machine tool. The quoted accuracy of these grade A sensors is $\pm(0.15+0.002|t|)^{\circ} \mathrm{C}$. The temperature measurement system includes a multiplexor that transfers the measured temperature data into a PC, the temperature data acquisition monitoring system with a real-time display, and automatic storage and export of measured data.

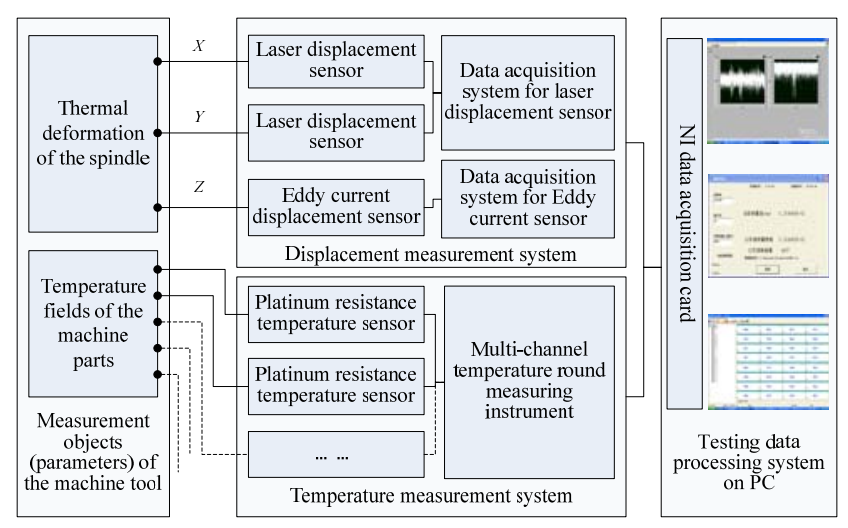

Fig. 1 Schematic diagram of the real-time measurement system

The displacement measurement system is composed of two laser displacement sensors, an eddy current 
displacement sensor and a displacement data acquisition system. The notional measurement resolution of the displacement sensors is $1 \mu \mathrm{m}$.

To transform the analog voltage signal sent out by the displacement sensors into a digital signal, a 16-bit data acquisition card is used. The card maintains 16-bit precision even when measuring all available 16 analog output channels at the maximum speed of $250 \mathrm{kS} / \mathrm{s}$. The displacement data acquisition system is programmed in the National Instruments LabVIEW language. The system gets experimental data from the data acquisition card, and the data analysis and processing are carried by the software.

Testing data processing method. The output signal from the displacement sensors measures the geometric form error induced by spindle radial runout, angular swing and axial shifting. The shape error from the spindle bar also has a periodic influence on the original measurement data. To reduce the system error, a rolling-mean filter is introduced in the displacement data acquisition system. See Fig. 2 for a schematic diagram.

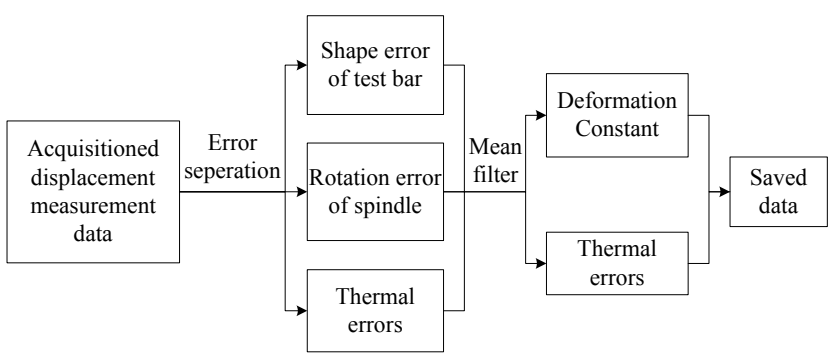

Fig. 2 Schematic diagram of rolling mean filter

The displacement measurement system collects 1200 items of data per second in each channel, so 7200 items of data are collecting in 6 seconds. The rolling-mean filter will calculate mean values from each of the 7200 data items and these mean values will be saved as the thermal origin errors. In this way, the shape error of the spindle test bar and the rotation error of the spindle can be expressed as single values. Therefore, we can obtain more accurate curves of the progress of thermal origin machining errors.

\section{Real-time measurement on vertical machining center}

As shown in Fig. 3, a vertical machining center is composed of a bed, a worktable, a column, a spindle box and spindle components. In practical manufacturing, the vertical machining center demonstrates significant heatgenerated error. To characterize the thermal performance of this vertical machining center, an experiment was conducted using our real-time measurement system. Temperature fields and thermal origin errors are represented graphically to analyze the thermal performance of the vertical machining center. This information allows effective optimization methods to reduce thermal origin errors.

Arrangements of temperature and displacement sensors. When the spindle of a vertical machining center is rotating without machining a workpiece, the heat generated by spindle bearings and the spindle motor is mainly distributed over the spindle components and spindle box. Heat is not significantly conducted to the column or other parts of the vertical machining center. Therefore, the platinum resistance temperature sensors are mainly arranged on the surface of the spindle components and spindle box. Tem- perature sensors are centralized near the spindle bearings and the spindle motor to detect the temperature of these sensitive points.

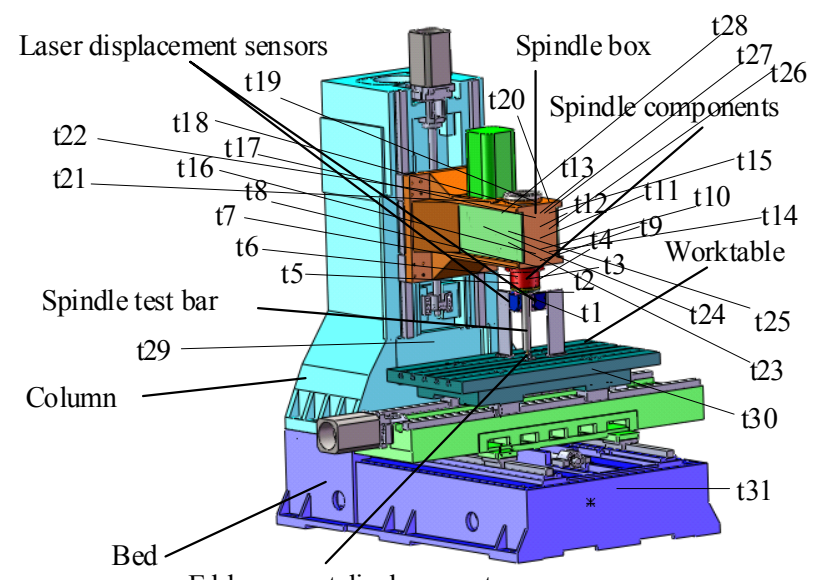

Eddy current displacement sensor

Fig. 3 Positions of the temperature and displacement sensors

To get the temperature fields over the whole vertical machining center, 32 platinum resistance temperature sensors are arranged as shown in Fig. 3, and the detailed locations of temperature sensors are given in Table 1.

Table 1

Positions of temperature sensors

\begin{tabular}{|c|c|}
\hline Sensor number & Location on machine \\
\hline $\mathrm{t} 1, \mathrm{t} 2$ & Spindle nose front \\
\hline $\mathrm{t} 3, \mathrm{t} 4, \mathrm{t} 5, \mathrm{t} 6$ & Spindle nose sides \\
\hline $\mathrm{t} 7, \mathrm{t} 8$ & Spindle flange \\
\hline $\begin{array}{c}\mathrm{t} 9, \mathrm{t} 10, \mathrm{t} 11, \mathrm{t} 12, \mathrm{t} 13, \mathrm{t} 14, \mathrm{t} 15, \mathrm{t} 16, \\
\mathrm{t} 17\end{array}$ & Spindle box front \\
\hline $\mathrm{t} 18, \mathrm{t} 19, \mathrm{t} 20$ & Spindle box top \\
\hline $\mathrm{t} 21, \mathrm{t} 22$ & Spindle motor \\
\hline $\mathrm{t} 23, \mathrm{t} 24, \mathrm{t} 25, \mathrm{t} 26, \mathrm{t} 27, \mathrm{t} 28$ & Spindle box sides \\
\hline $\mathrm{t} 29$ & Column \\
\hline $\mathrm{t} 30$ & Worktable \\
\hline $\mathrm{t} 31$ & Bed \\
\hline $\mathrm{t} 32$ & Ambient \\
\hline
\end{tabular}

The thermal origin errors can be measured by measuring the displacement of a spindle test bar that is assembled in the vertical machining center. Two laser displacement sensors are fixed on the worktable to measure the displacement errors of the $\mathrm{X}$ and $\mathrm{Y}$ axes. The direction of the laser beam and the distance between the laser displacement sensors and the spindle test bar are adjusted to make sure the laser beam is aligning to the center of the spindle test bar along the axis and focusing on the surface of the spindle test bar. The eddy current displacement sensor is placed below the bottom of the spindle test bar on the worktable to detect errors of the vertical machining center $\mathrm{Z}$ axis. The displacements between displacement sensors and measured position are adjusted to make sure that it is within their measurement ranges. The displacement sensors are arranged as shown in Fig. 3.

Photographs of the experimental setup for temperature and displacement measurements are shown in Fig. 4. 

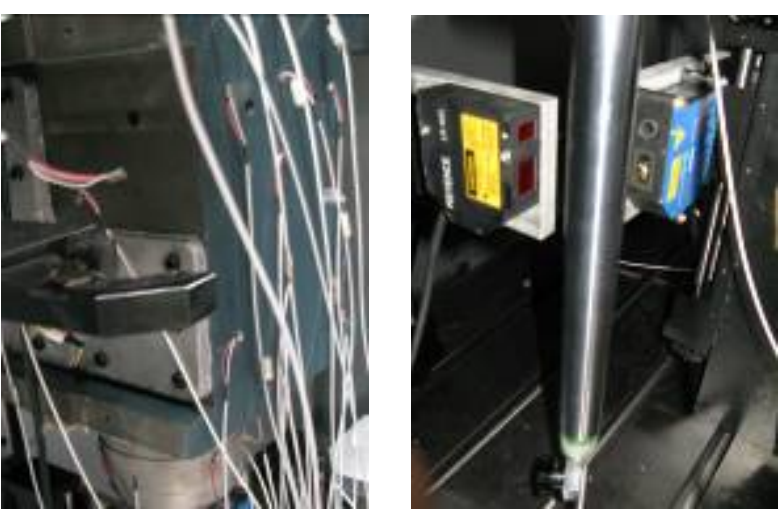

Fig. 4 Experimental setup

Experimental data analysis. Experiments were carried out on a vertical machining center to study its thermal performance. The temperature data from the temperature data acquisition monitoring system are saved as a Microsoft Excel spreadsheet file, and thus we can draw a series of curves to represent the temperature fields (Fig. 5).

Fig. 5 shows that the ambient temperature negligible variation in the first 7 hours. After the central air conditioning of the workshop is shut down, the ambient temperature increases by $3.2^{\circ} \mathrm{C}$ in 1.5 hours. This is enough to have a measurable effect on machine tool error.

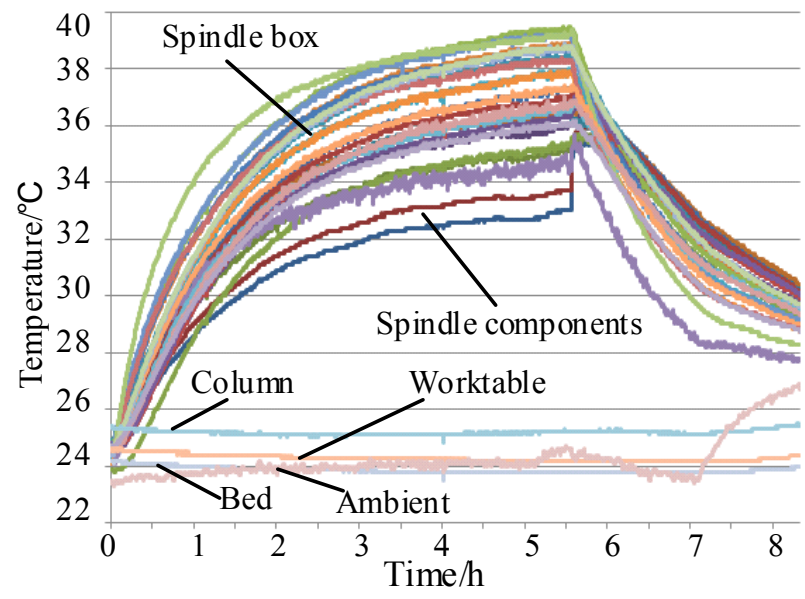

Fig. 5 Temperature fields over the whole machine

Because the spindle bearings and spindle motor are the main sources of heat, the temperatures of spindle components and the spindle box rise up immediately when the spindle starts to rotate at the set speed of 6000 revolutions per minute, and the temperature decreases rapidly after the spindle is stopped. The column, worktable and bed are far away from the heat sources, so little heat is transferred to them, and the temperature is correspondingly constant. The maximum temperature rise of $14.6^{\circ} \mathrm{C}$ appears on the surface of the spindle box near the back bearing group. The temperature sensors symmetrically distributed on the $\mathrm{Y}$ axis of the vertical machining center show the same temperature rise. This means that the temperature fields of the vertical machining center are symmetrical on the $\mathrm{Y}$ axis. This is related to the structure of the spindle components and spindle box.

Temperature fields on the surface of the vertical machining center are influenced by both machine generated heat and ambient temperature changes. These ambient changes can affect the temperature fields of the entire ver- tical machine center

The thermal origin error data from the displacement measurement system are saved in a Microsoft Excel spreadsheet file. Thermal origin error curves from original experimental data are shown in Fig. 6.

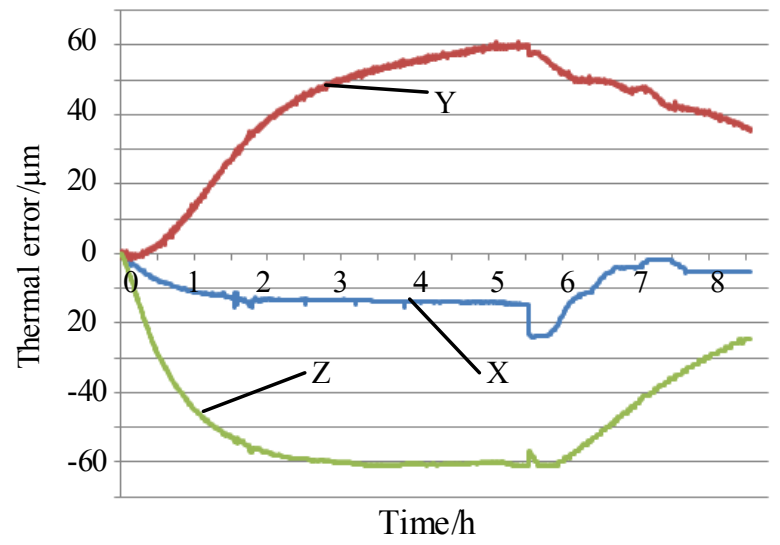

Fig. 6 Thermal origin errors of the machine spindle

Fig. 6 shows that the thermal origin machining error curves have sudden changes when the spindle is shut down. This represents the geometric form error induced by spindle radial runout, angular swing, axial shifting and the accuracy of the spindle test bar. The saved experimental data include the constant geometric form error when the spindle is rotating. After the spindle is shut down, each of the displacement sensors only measures the displacement of a single point on the spindle test bar. The constant value of the geometric form error changes so that thermal origin error curves show step changes.

The thermal origin error of the $\mathrm{X}$ axis reaches steady state in 1.5 hours and the final maximum thermal origin error is $12 \mu \mathrm{m}$. That is because the thermal origin error of the $\mathrm{X}$ axis is mainly induced by the thermal expansion of the spindle components and the spindle box along the $\mathrm{X}$ axis. The temperature fields and structure of the vertical machining center are symmetrical on the $\mathrm{Y}$ axis. The spindle test bar is in the center of the spindle, so the displacement of this axis is quite small.

It takes almost 5 hours for the thermal origin error of the $\mathrm{Y}$ axis to reach a steady state. The final maximum thermal origin error of $Y$ axis is $62.5 \mu \mathrm{m}$. The maximum thermal origin error is along the $\mathrm{Y}$ axis, and it can be attributed to the thermal expansion of the spindle box.

The thermal origin error of the $\mathrm{Z}$ axis reaches a steady state in 2.5 hours and the final maximum thermal origin error is $61 \mu \mathrm{m}$. The thermal expansion of the spindle and spindle box is the main source of this thermal origin error.

The thermal origin error increases rapidly in the first 1.5 hours. In the traditional practical machining process, vertical machining centers are usually started without machining for half an hour or more. This is a way to reduce thermal origin errors by preheating the vertical machining center. When the spindle is shut down, the vertical machining center cools in the air. Its temperatures decrease and the thermal origin errors begin to fall back.

Optimization of the thermal performance. Because the temperature rise is mainly concentrated in the spindle box and spindle components, the optimization of the thermal performance should be focused on reducing the 
temperature rise of the spindle box and spindle components. Channels could be cut in both sides of the spindle box. Cooling oil could be pumped through the channels to carry away the heat in the spindle box; this heat originated in the spindle components and the spindle motor. In this way, the whole temperature rise of the vertical machining center is reduced, and the thermal origin machining errors are consequently decreased. Methods for thermal origin error compensation should clearly be the subject of further investigation.

\section{Conclusions}

A real-time measurement method for temperature fields and thermal origin machining errors in machine tools is introduced, and experiments were carried out on a vertical machining center. Thirty-two platinum resistance temperature sensors are used to measure the temperature fields. Two laser displacement sensors and an eddy current displacement sensor are used to measure the thermal origin displacement errors of X-, Y- and Z-axes of the machine spindle. To get more accurate parameters relating to thermal properties, a rolling mean filter is introduced in the data processing to eliminate the geometric form error induced by spindle radial runout, angular swing and axial shifting the systematic error introduced by the thermal deformation of the aluminum plate for fixing the laser displacement sensors are considered as part of the data processing. The results show that the measurement system performs precise and stable characterizations. We find that thermal origin machining errors in the vertical machining center are significant. They are of sufficient magnitude to have a notable influence on the accuracy of the machined workpiece. Methods to reduce thermal origin errors such as cooling the spindle motor, by means of cooling channels in the sides of the spindle box, are also discussed.

\section{References}

1. Yang, S.H.; Kim, K.H.; Yong K.P. 2004. Measurement of spindle thermal errors in machine tool using hemispherical ball bar test, International Journal of Machine Tools \& Manufacture 44: 333-340.

2. Ramesh, R.; Mannan, M.A.; Poo, A.N. 2003. Thermal error measurement and modelling in machine tools. Part I. Influence of varying operating conditions, International Journal of Machine Tools \& Manufacture 43: 391-404.

3. Lee, D.S.; Choi, J.Y.; Choi, D.H. 2003. ICA based thermal source extraction and thermal distortion compensation method for a machine tool, International Journal of Machine Tools \& Manufacture 43: 589-597.

4. Krulewich, D.A. 1998. Temperature integration model and measurement point selection for thermally induced machine tool errors, Mechantronics 8: 395-412.

5. Kačeniauskas, A.; Česnienè, J. 2006. Coupled FEM simulation of turbulent flow and temperature in insulated pipes, Mechanika 5(61): 32-37.

6. Tseng, A.A.; Chaidilokpattanakul, C.; Chen, J.S.; Westgate, C.R. 1997. A Fast electro-optical sensing system for measuring thermal response of a rotating roll without generating contact noise, Journal of Manufacturing Science and Engineering 119: 193-200.

7. Leshock, C.E.; Shin, Y.C. 1997. Investigation on cut- ting temperature in turning by a tool-work thermocouple technique, Journal of Manufacturing Science and Engineering 119: 502-508.

8. Li, S.H.; Zhang, Y.Q.; Zhang Guoxiong. 1997. Study of pre-compensation for thermal errors of NC machine tools, International Journal of Machine Tools and Manufacture 37(12): 1715-1719.

9. Li, Y.X.; Li, Y.Y.; Cao, H.T.; Jin, Y.Q.; Yang, J.G. 2008. Study on checking and measurement of doubleball bar for thermal errors of CNC machine tools, Key Engineering Materials 375-376: 544-548.

10. Linares, J.M.; Sprauel, J.M.; Bourdet, P. 2008. Geometrical checking by virtual gauge, including measurement uncertainties, CIRP Annals - Manufacturing Technology 57(1): 513-516.

11. Feng, Q.B.; Liang, J.W. 1994. Study of high precision measurement of large diameters by a dual frequency laser interferometer Chinese Journal of Lasers B (English Edition) 3(6): 543-552.

12. Gloeckner, P.J.; Kokini, K.; Stevenson, W.H. 1992. 3-D measurement of thermal deformations on an ultrahigh density circuit module with a laser range probe, Intersoc Conf Therm Phenom Electr Syst I THERM, 92: 165-169.

13. Zhao, H.T.; Yang, J.G.; Shen, J.H. 2007. Simulation of thermal behavior of a CNC machine tool spindle, International Journal of Machine Tools and Manufacture 47(6): 1003-1010.

14. Povilionis, A.; Bargelis, A. 2010. Structural optimization in product design process, Mechanika 1(81): 6670 .

\section{Chen, J.F. Zhang, Z.J. Wu, P.F. Feng}

\section{METALO PJOVIMO STAKLIŲ TEMPERATŪROS \\ LAUKŲ IR ŠILUMINIŲ PAKLAIDŲ TYRIMAS REALAUS LAIKO MATAVIMO METODU}

R e z i u m è

Straipsnyje pristatomas metodas realaus laiko temperatūros lauku ir šiluminių paklaidų metalo pjovimo staklèse matavimams tirti naudojant subalansuotą platformą, kuri yra sudaryta iš matavimo objektų, poslinkių matavimo sistemos, temperatūros matavimo sistemos ir bandymo duomenų apdorojimo sistemos. Temperatūros pokyčiams metalo pjovimo staklèse nustatyti naudojamos platininès varžos. Labai tikslūs lazerinio poslinkio jutikliai ir nuolatinès srovès poslinkio jutikliai naudojami staklių suklio šiluminei paklaidai $\mathrm{X}, \mathrm{Y}$ ir $\mathrm{Z}$ ašių kryptimis matuoti. Norint gauti tikslesnius bandymų duomenis, panaudotas filtras signalų apdorojimo metu dèl suklio radialaus sukimosi, kampinio svyravimo ir ašinio pasislinkimo atsiradusioms geometrinès formos paklaidoms pašalinti. Ant vertikaliojo apdirbimo centro atlikto bandymo duomenys buvo analizuojami naudojant duomenu apdorojimo sistemą. Rezultatai parode, kad matavimo sistema ir bandymo metodas yra labai tikslūs ir efektyvūs. 
C. Chen, J.F. Zhang, Z.J. Wu, P.F. Feng

REAL-TIME MEASUREMENT OF MACHINE TOOL TEMPERATURE FIELDS AND THEIR EFFECT ON MACHINING ERRORS

S u m m a r y

This paper presents a method and apparatus to carry out real-time measurement of temperature fields and thermal origin machining errors in machine tools. Experiments are performed on a vertical machining center, and the experimental data are analyzed in the data processing system. Displacements and temperatures are measured during machine tool operation. Platinum resistance sensors are used to collect the temperature changes. High accuracy laser displacement sensors and an eddy current displacement sensor are used to measure the thermal origin errors in the positioning of the machine spindle in the $\mathrm{X}-, \mathrm{Y}-$ and $\mathrm{Z}$-axes. To get more accurate experimental data, a rollingmean filter is introduced in the signal processing to eliminate the geometric form error induced by spindle radial runout, angular swing and axial shifting. The results show that the measurement system and testing method is highly efficient and precise.

Received April 05, 2011 Accepted June 30, 2011 